\title{
THE VULNERABILITY AND RATIONALISATION OF PROSTITUTES WITHIN MERITOCRATIC CAPITALISM SOUTHEAST ASIAN MIGRANT WORKERS IN TAIWAN
}

Mingchang Wu, ${ }^{*}$ Farhad A. K. Cassim, ${ }^{2}$ Suryaneta Binti Masrul ${ }^{3 * *} \&$ Richard Yanato 4

${ }^{*}$ First author, ${ }^{* *}$ corresponding author

1,3,4 Graduate School of Technological and Vocational Education, National Yunlin University of Science and Technology, Taiwan, R.O.C.

${ }^{2}$ General Education Centre, National Yunlin University of Science and Technology, Taiwan, R.O.C.

(wumc@yuntech.edu.tw, cassim@yuntech.edu.tw, suryaneta@gmail.com,

D10643016@yuntech.edu.tw)

DOI: https://doi.org/10.22452/jati.vol26no1.4

\section{Abstract}

This study sought an insightful understanding of the effects of meritocratic social capital-an inevitable phenomenon/mechanism whereby individuals receive social recognition, respect, and other benefits due to their monetary achievement-on Southeast Asian migrant workers' behaviours and their ingrained perceptions through investigating their life stories and inner voices reflecting the factors inducing them to participate in the prostitution world. Interpretative Phenomenological Analysis (IPA) was employed to scrutinise the qualitative data collected from a series of in-depth interviews with four Southeast Asian migrant women in Taiwan. This study led to the following conclusions: (1) These migrant workers moved overseas due to their pure and simple intention of pursuing better lives for themselves and their family; (2) The internal factors (family reputation and wellbeing) and external ones (unexpected events and a meritocratic society) simultaneously pulled and pushed them, eventually turning them out of their normal careers; (3) They were stuck in the very depths of an extravagant but vicious world by the shock, even attraction, of "big money" characterising a meritocratic capitalist order; and (4) Innocence and 'purity' get lost easily, even unconsciously, in the social context of meritocratic capitalism and wishful rationalisation of questionable behaviours, flouting convention and morality, with self-sacrifice and compensation, and self-rationalisation.

Keywords: female migrant worker, meritocracy, prostitution, rationalisation theory 


\section{Introduction}

I am so happy to know my sister used my remittance to buy a house with a big yard for my family. My cousins enviously want to come here [Taiwan] too, when they saw my pictures here [in Taiwan] and my new house [in her home country]. My parents and family members do not know what I am doing here [prostitution]. They had better not know it. I will not do this job anymore when I make enough money and go back to my country.

- from the interview with Nina (pseudonym), a former caregiver who had immigrated from a Southeast Asian country to Taiwan and who became a prostitute after unexpected miseries in her career.

This is the inner voice, true but hopeless, of Nina, who changed her career from a caregiver into an overseas prostitute to support her family better financially. As the breadwinner of their families and as one of the many Southeast Asian female migrant workers in Taiwan, women like Nina, initially come to Taiwan legally as elderly caregivers or factory labourers. These women have more advantages over men in seeking a job in the social welfare sectors because, in Taiwan, the aging population has a higher demand for household helpers or caregivers (Liang, 2011).

The rapidly growing number of mainly Indonesian, Vietnamese, and Filipino Southeast Asian migrant workers who have come to Taiwan over the decades has received the attention of many scholars because of the embedded social and cultural issues (Deng, Wahyuni, \& Yulianto, 2020; Hoang, 2016). In 1989, Taiwan started recruiting foreign workers to meet the labour needs of the construction workforce; later, at the beginning of 1992, female migrant workers were allowed to work as caregivers or domestic helpers. To date, according to a report from Taiwan's Ministry of Labour, by April 2021, Taiwan received a steadily increasing number of foreign migrant workers, reaching around 713,454, with $66 \%$ among them employed in productive industries (agriculture, forestry, fishing, manufacturing, construction, and the like) and 34\% in social welfare and services as caregivers and domestic helpers (Ministry of Labor Taiwan, 2021). Deng et al. (2020) highlighted that these migrant workers worked overseas under the theory of "push and pull". Unfavourable conditions (e.g., high employment rates) "push" people out and better external attractive forces (e.g., high labour demand rates) "pull" people in.

Most of the 245,057 caregivers or house helpers are women from Indonesia (75\%), Vietnam (13), the Philippines (11\%), and other countries (1\%) (Ministry of Labor Taiwan, 2021). Additionally, these individuals mainly came from the rural 
areas of their home countries (Liang, 2011). The social and cultural differences between their home countries and Taiwan inevitably creates multiple conflicts arising from culture shock and a different sense of value (Chen, Lin, \& Sawangpattanakul, 2011). Typically, they are exposed to an economically developed society characterised by meritocratic moneyism (Poocharoen \& Brillantes, 2013), an inevitable phenomenon/mechanism whereby individuals receive social recognition, respect, and other benefits due to their monetary achievement (Konings, 2015).

This reality in the era of the neoliberal market influences the mind-sets of people like Nina. The tenacious pursuit of secular goals stimulates individuals to pursue more and more wealth; monetary achievement is used to identify each individual's success (Fergnani, 2019). A sense of achievement subsequently dominates each person's intention and orients their behaviours toward reaching a higher social status, even leading them to temporarily put aside the justifiability and morality behind the means they choose to reach their goals. In the subconsciousness and social expectation of individuals, the conviction that "working hard is the secret to success" frequently prevails and motivates them to pursue higher secular achievements. These visible but external achievements seem pivotal in most people's lives and dominates social judgment (Konings, 2015). This circumstance triggers the vulnerability of some people like Nina; while they work hard to achieve their goals, they may potentially disgrace themselves by taking on unimpressionable careers, such as that of a prostitute.

Despite the hotly debated issues among scholars in the conceptualisation of prostitution (Campbell, 2015), in some cultures and religions, prostitution is still a gendered occupation with women representing a troubling figure and being stigmatised as possessing immoral vanity (Yacoub, 2019). This social stigma creates devastating impacts on a prostitutes' identity. Taking an example from a study of Gorry, Roen, and Reilly (2010), a prostitute described her job as: "it makes you feel horrible, it makes you feel like you are nothing...it knocks your confidence, it makes you feel like you are just gross" (Gorry et al., 2010, p. 495). Moreover, marginalised groups of migrant workers who become prostitutes suffer a double stigma because of their identity as foreign labourers and prostitutes (Oliveira, 2012).

The present study aimed to deeply understand the life stories and inner voices of female migrant workers who changed their careers to that of a prostitute and the effect of meritocratic moneyism on their behaviours and perceptions. The dynamic life trajectories of these women started with the initial intention to work overseas as foreign labourers, progressed toward the experience of culture shock 
and value conflicts, and eventually culminated in a career change (Figure 1). People, such as migrant workers, usually work for survival and better life qualities. However, some things happen in their lives, typically in the context of a meritocratic society, that conflicts with their sense of value and eventually orients them to changing their money-making approaches and careers.

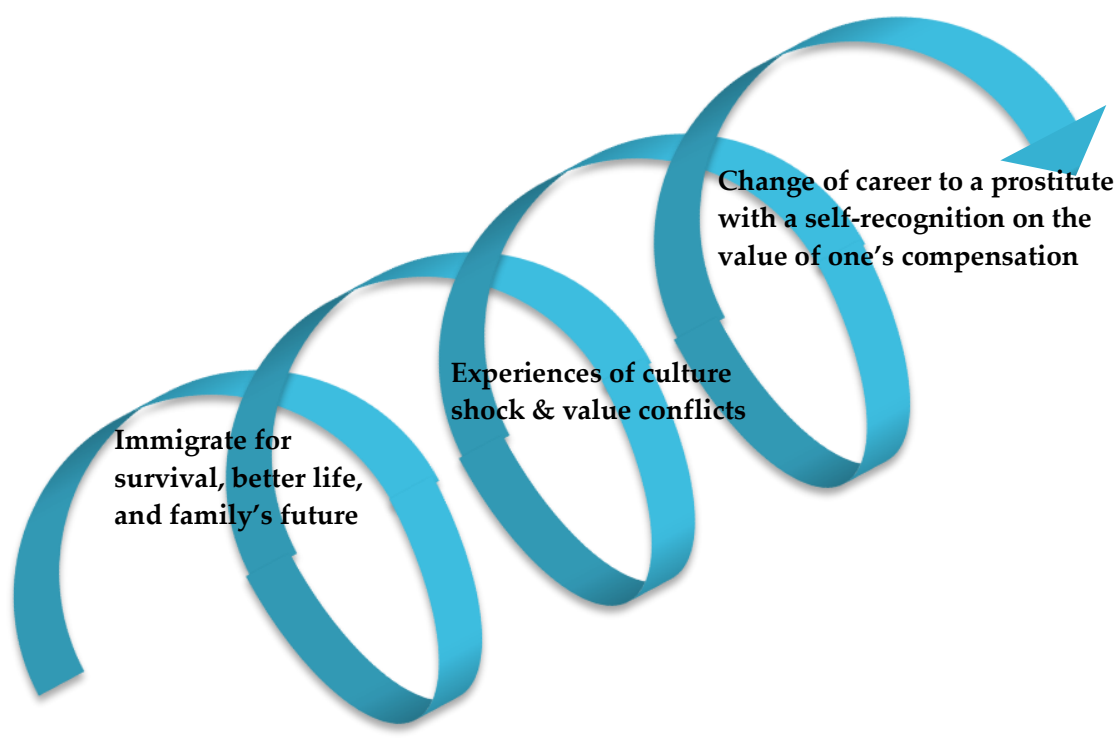

Figure 1: Research conceptual framework

A better understanding of these dynamic life trajectories and a reflection of previous literature and relevant theories will assist social workers, mainly migrant worker activists. Interventions and/or policy amendments by nongovernmental organisations (NGO) and related stakeholders can be inspired on the basis of the insightful information the study garnered from the participants' personal perspectives and social meanings behind their lived experiences.

In line with the research purpose, this study focused on the following major questions: From entering the world of prostitution to the their current life, how did their life stories develop? How do they perceive themselves and their responsibility to their family and then adjust themselves to a society with meritocratic moneyism? 


\section{Literature Review}

\section{Meritocratic Moneyism}

Warikoo and Fuhr (2014) defined a meritocratic society as a social system that distribute rewards purely on the based on intelligence and skill. In line with this idea, Kim and Choi (2017) assert that "meritocracy is a social system in which advancement in society is based on an individual's capabilities and merits rather than on the basis of family, wealth, or social background" (Kim \& Choi, 2017, p. 112).

The etymological definition of "merit" has become crucial when describing what meritocracy is. The British sociologist Michael Young, who first coined the term meritocracy in his book The Rise of Meritocracy in 1958 formulated merit as strictly involving IQ + effort. Later, some scholars defined merit as ability, experience, and training (Hing et al., 2011), skill (Warikoo \& Fuhr, 2014), wealth (Meroe, 2014), or achievement (Shane \& Heckhausen, 2017).

In this study, we specifically define "merit" as "moneyism", a monetary achievement that highly values money or something equal to money, including luxury goods, extravagant cars, high-tech smartphones, branded watches, and the like (Bell, 2012; Duru-Bellat \& Tenret, 2012). Today, in the era of the neoliberal market, people use monetary achievements as icons and worships of wealth (Konings, 2015), then narrate it as a salient point to depict their success (Fergnani, 2019). Bettache, Chiu, and Beattie (2020) referred to the competitive market in neoliberalism as "the merciless mind of a dog-eat-dog society", an ideology that preserves each individual in society through superficial freedom and equal opportunities. In concrete terms, it leads to a society where some dominate policies and/or resources in order to take advantage of others, while others, typically those of an underprivileged status, constantly suffer and struggling with limited resources and opportunities.

Furthermore, the dark side of meritocracy results in certain unprivileged people encountering inequality of opportunities while hard work cannot alter the cruel fact of a scarcity of resources. (Cargile, Mao, \& Young, 2019; Lipsey, 2014). These circumstances trigger some people with disadvantages to engage in something against social norms, such as prostitution (Coşkun, 2018; Oliveira, 2012) or criminal conduct (Nkansah-Amankra, Agbanu, \& Miller, 2013). That is, meritocratic moneyism encourages people to strive for a higher achievement while simultaneously inducing a loss of self in the journey of pursuing monetary achievement. 


\section{Rationalisation Theory and System-Justification Theory}

People habitually rationalise their guilty and shameful behaviours resulting from the violation of laws or social norms. Rationalisation is a large and varied concept in the psychological literature. In his research, Cushman (2020) highlighted that "cognitive dissonance" is the most widely used concept in describing the rationalisation process. People rationalise their past actions or behaviours by changing their preferences, beliefs, or desires to fill "cognitive dissonances".

Cushman (2020) further emphasised that people concoct new beliefs and desires to rationalise their behaviours or actions. He also proposed the function of instincts, norms, and habits to improve the reasoning process, as shown in Figure 2. In a commentary to Cushman's study, Laurin and Jettinghoff (2020) tried to reconcile rationalisation theory and system-justification theory by asserting "rationalisation means both justifying one's behaviors (per Cushman) and trying to feel better about the world one lives in (per system-justification)" (Laurin \& Jettinghoff, 2020, p. 39).

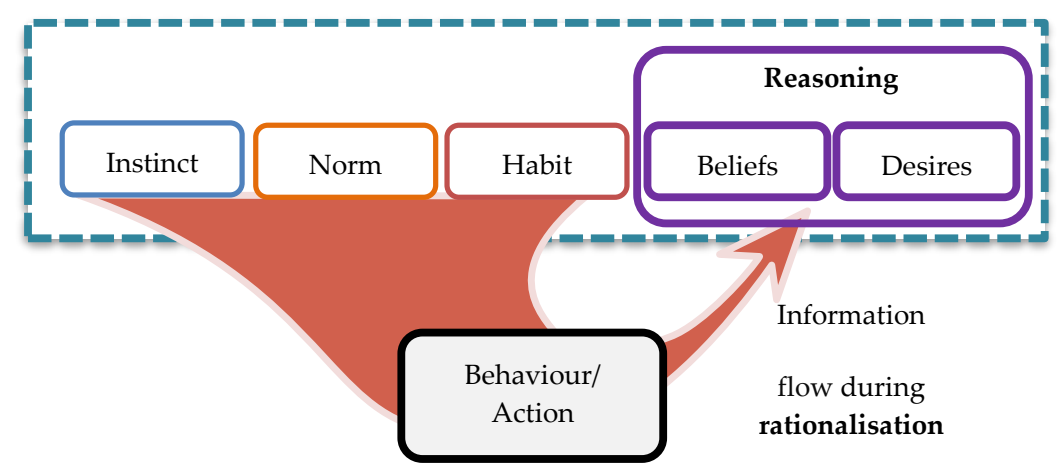

Figure 2: The function of instinct, norm, and habit to improve reasoning (beliefs and desire) during the process of rationalisation (Cushman, 2020)

In system-justification theory, individuals attempt to achieve selfaffirmation through the "manipulation" of positive thinking when encountering the current system's negative features (Jost \& Hunyady, 2005). In line with this concept, Ledgerwood, Mandisodza, Jost, and Pohl (2011) noted that faith in meritocracy is also associated with this system-justification theory. People tend to "manipulate" their cognition and behaviour to achieve the belief that social hierarchies are fair and legitimate. The concept of "cognitive dissonance" explains both rationalisation theory and system-justification theory through beliefs, 
desires, instincts, norms, and habits that have a function of improving reasoning processes (Figure 3).

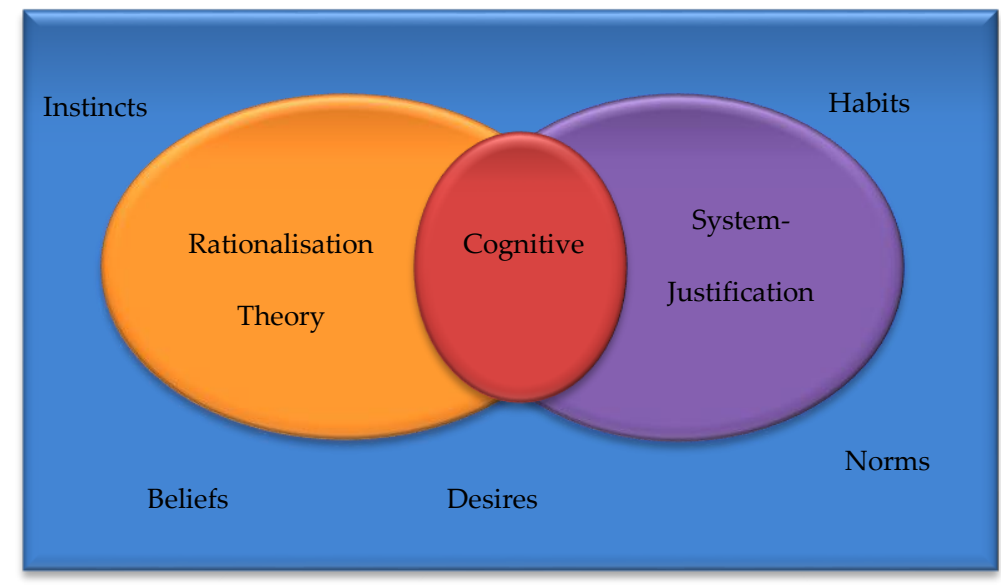

Figure 3: Rationalisation and social justification theory (modified from Cushman [2020] and Laurin and Jettinghoff [2020]).

\section{Interim Summary}

The pure orientation of migrant workers coming from overseas toward an economic survival shifts to an orientation to the social class ladder. In a society of meritocratic moneyism, the migrant workers' sense of value is challenged and changed in accordance with their experiences and money-making approaches; their mindsets change. Meritocracy motivates individuals to pursue higher achievement and better lives; yet, it also inevitably misleads them into a dark abyss as they fall increasingly into a scarcity mindset and a lack of self-consciousness and self-understanding. Alternative approaches to earning big money push migrants into the abyss of career despair. They subsequently transform and rationalise their recognitions or behaviours by obscuring the reasons for their success, family reputation, and social status.

\section{Research Methodology}

Phenomenology as a framework of inquiry (Neubauer, Witkop, \& Varpio, 2019) was aligned with the research purpose, which was to develop a deep understanding and interpretation of phenomena through events or emotional experiences. In this research, the Interpretative Phenomenological Analysis (IPA) was employed as an ideographic method that examined each entity in detail before moving on to a more general claim. IPA aims to understand the participants' life 
experiences and focuses on the way people perceive their motivations and behaviours. IPA is usually employed to deeply investigate small samples in order to gain rich-insightful understandings and reflective interpretations while reaching data saturation (Smith, Flowers, \& Larkin, 2009).

Using purposive sampling, the participants were recruited through a researchers' friend who was active in her immigrant association. The researchers' friend, having worked as a part-time prostitute for years, also volunteered to serve as a participant. The other participants were invited through this participant's network and interviewed in some restaurants and parks in which they felt comfortable and safe until the researchers reached sufficient and saturated data to understand and interpret the proposed questions (Seidman, 2006). Table 4 shows the informants of this study with pseudonyms to protect their identity.

It was quite challenging to find the informants because of the nature of this study, thus the researchers implemented these interviews and reflections from September 2020 to April 2021. Over this period, the researchers recruited and interviewed participants and reflected on the meanings behind the transpired phenomena as data saturation was being reached.

It needs to be recognised that there are profound ethical implications and sensitivities in recruiting and interviewing people who take illegal work or stigmatised jobs. Hence particular attention was taken to protect the participants' safety, anonymity, and confidentiality. Therefore, researchers requested the informed consent of all participants; however, while the participants agreed to be interviewed, they refused to sign an informed consent form in order to protect themselves as well as their family's reputation.

The collected data were analysed following the seven steps of Interpretative Phenomenological Analysis (IPA) outlined in Smith et al. (2009) and by focusing on the participants' life experiences and their thoughts, motivations, behaviours, and reflections.

Table 1: Participant profile

\begin{tabular}{lclll}
\hline $\begin{array}{l}\text { Participants' } \\
\text { pseudonym }\end{array}$ & Age & City in Taiwan & $\begin{array}{l}\text { Year entry } \\
\text { Taiwan }\end{array}$ & $\begin{array}{l}\text { Length of time in } \\
\text { prostitution }\end{array}$ \\
\hline Maria & 30 & Kaohsiung & 2011 & 6 years \\
Annie & 29 & Kaohsiung & 2013 & 4.5 years \\
Jean & 25 & Taichung & 2014 & 5 years \\
Nina & 34 & Miaoli & 2012 & 6 years \\
\hline
\end{tabular}




\section{Research Findings}

Through their narrations, the four participants shared their life stories about their pathways to prostitution, the factors causing their career change, and the consequent lifestyles they experienced in a society of meritocratic moneyism. Figure 4 outlines the major themes: the intention to pursue better lives, the benefit and guilt encountered in the context of meritocratic moneyism, and the rationalisation processes they underwent in terms of their 'disgraceful' behaviours.

\section{They possess a high intention to pursue better lives}

Poverty, urgent financial help for one's family, and a low social-economic status forced them to separate from their family in their home country. For example, Maria expressed:

I do not have any choice. My husband cannot find any job in our homeland. My daughter already needs to go to primary school and needs money. I hope she will not become like us, her parents, who do not have an educational background. I hope, in the future, she can become an intelligent person.

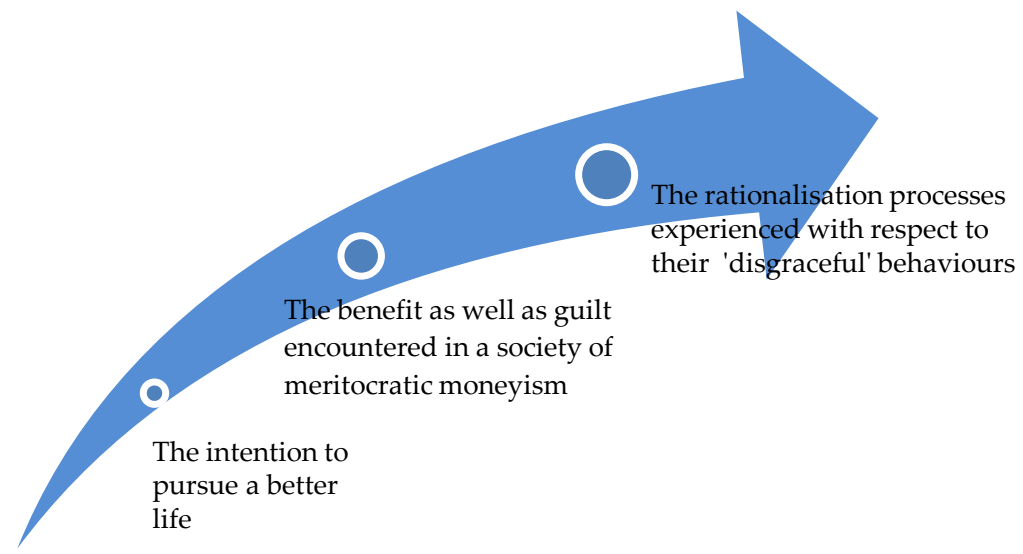

Figure 4: An overview of main themes

The high hopes of fleeing overseas, which they thought might help them raise their family, forced them to sell their family assets or even led them to borrow 
money from a loan shark for a job placement fee requested by an agency. Annie described how she prepared the agency fee:

When I come to Taiwan, I do not have enough money. I borrow it from family and neighbors as an agency fee. Some of my friends must borrow from a loan shark with high interest because their family or neighbors do not have money....

These individuals overlooked the limitations and barriers of poverty to pursue a better future for themselves and their families. However, it was not easy working overseas. They suffered from the difficulties of language barriers, cultural differences, and even disdainful looks because of society's perception of their work and themselves as being low status. As Nina said, "I could not understand their language, often misunderstood their order [rules] and made some mistakes". The ladies were extremely displeased about their work due to the heavy load and lack of respect associated with it as illustrated by Annie's remarks when she mentioned, "They do not respect me, do not even appreciate my dirty and tedious work, do not want to do it [the dirty work], and hire me to do that". Annie's experiences echo Lin and Bélanger's (2012) assertion that "domestic workers were generally more vulnerable to isolation, exploitation, and abuse than migrants who work in non-domestic sectors".

\section{They encountered benefits as well as guilt in a society of meritocratic moneyism} Initially, the participants came to Taiwan with personal dreams and family expectations, worked hard in peace alongside others. Unfortunately, they had could not help but make significant career changes due to some unfortunate events or the unavoidable temptations of money; they felt trapped in lives without enough financial income or social support and urgently searched for better means of survival. Some alternative approaches to making a living, even earning big money and living glamorously, evidently attracted them. In this way, they were unconsciously pushed into the deep world of prostitution. Stated simply, our study concluded while the participants faced a high pressure to raise their family and make their original dreams come true, some unexpected or unfortunate events occurred and subsequently induced them to change their career track. Each participant narrated their different story as follows: 


\section{Maria}

Maria, a 30-year old woman, came to Taiwan in 2011 as a caregiver, to mainly take care of an elderly man in Kaohsiung, located in Southern Taiwan. After the first six months, her employer started to harass her by indecently touching her. Despite lodging several protests, he continued his behaviour and finally raped her. Maria reported these harmful and tragic circumstances to her agent but received no positive response. As such her malignant employer continued to rape her for three months. Eventually, feeling she had no choice, Maria ran away and became an illegal worker, dramatically increasing her vulnerability.

Without any reliable job in Taiwan, Maria was put in a tight spot; she had no fixed place of accommodation and could only take on some temporary jobs illegally on a weekly basis. What is more, she was required to send money back to her family as usual, yet could not inform them of her predicaments in Taiwan. Her primary mission for working overseas was to earn more money and send it back home, representing her career achievement and enabling her to take her place as a proud member of her family and even of society. Maria said:

I was raped multiple times by my employer in the first nine months in Taiwan [in my first job of nine months in Taiwan]. Instead of helping [me], my agent scolded and called me a liar. Desperately, I run [ran] away, becoming an illegal worker wandering around with an unsteady job and income. This happened [for] almost for [sic] two years.

After living in a rather unstable manner for two years, Maria met a friend from her country, living in prostitution, and started to pursue an alternative way of making a living. Initially, she did not feel comfortable about this shameful occupation. Gradually, however, the living pressure and urgent demands of sending money home convinced her to work as a prostitute. She transitioned from working part-time to working full-time in this occupation. She sobbed out her grievances:

At that time, the main reason that concerned me was my family. I must get money and send it to my family. Besides that, my first employer already raped me. I think I was dirty, and this is maybe the best work for me as a prostitute. I do not want [to live] my life like a bum like the past few years. 


\section{Annie}

Annie, a 29-year old woman, also stays in Kaohsiung. She got her working permit as a nursing lady and came to Taiwan in 2013. In the first two years, everything ran smoothly as she had expected. Consequently, she regularly sent her salary back to her husband in her home country. Unfortunately, in the third year of employment, Annie's parents informed her that her husband had another woman and ran away from her family with all the money, leaving her 3-year old child with her parents. Annie shared her feelings regarding this circumstance:

At that time, I heard from my parents that he just gave my family a little money every month. Every month when I got my salary, I always sent it to my husband's bank account. I trusted him, but he lied to me. I worked hard here then [but] he spent the money with [on] another woman.

In the first few weeks after hearing about that news, she was too depressed to work. Finally, the nursing home and agency decided to break her contract and sent her back to her home country. This ensuing problem further hurt her profoundly as it broke her dreams of making a better future for herself and her family through working overseas. Finally, she ran away and got a new but illegal job as a caregiver for an elderly man.

The new employer was very nice. She got a vacation every weekend because the man's children stayed at home with him and his wife. On her weekend breaks, she got acquainted with a man from her own country. That romantic opportunity brought back new hope and an intention to begin a new love story. Nevertheless, six months after they had their first intimate encounter, the man confessed he already had a family in their home country and wanted to stop their relationship. Annie's heart was broken again. She thought she could find a man who would be a worthy replacement for her ex-husband. Annie said:

From that time until now, I think, all men are the same. They only want to play with women. They do not want to have a serious relationship. After they get 'all of us' [sleep with us], they will throw us [away] like rubbish. I do not want to have a close relationship again with [any] men.

This series of unfaithful experiences triggered her to hang out and even have sex with men without being in a serious relationship with them. At the beginning, no money was involved, but later on, she requested payment for their intimate encounters. 
Jean

Jean works in Taichung, located in the middle of Taiwan, and is a legal worker unlike the first two women. Her employer gives her a vacation every weekend. She spends her weekends at a club with her friends. Before coming to Taiwan, she frequently changed her sex partner.

Six months after arriving in Taiwan, this 25-year old girl started to engage in prostitution. She thought her salary from her caregiver's job was insufficient to support her in buying a brand-new phone and other luxury items. Jean asserted:

I made new friends, and we go [often] to a club. My friends have highend branded cell phones and luxury items with them. I need more money for this new lifestyle, but my salary is not enough. So, I begin [began] to earn extra money by having sex with men.

Jean also indicated in the interview that charging the men she met for these encounters allowed her to simultaneously get sex partners and money for anything she wanted. Despite this, Jean is vehemently against sleeping with a man if she does not like him, even if the man is willing to pay a high compensation.

\section{Nina}

Nina, a thirty-four-year-old woman, is currently a nursing lady in Miaoli, a small county in central Taiwan. Nina got a working permit in 2012 to be a nursing lady in Taichung. After two years of working in Taichung city, she met her hometown friends who had sufficient spending money and dressed fashionably for weekend parties. She described her friends as follows: "My friends wore fashionable dresses and showed me their sufficient allowance [sic] [spending money]. They told me that they could easily get extra money by giving service [prostitution]".

She realised that it was easy to make extra money as a part-time prostitute in Taiwan without ever being known for this by her family in her hometown. At the beginning, she felt shameful and guilty but ecstatic when she received the 'extra money' after a couple of hours. Gradually, she began to enjoy the "big money", the occasional sex activities, and even the passionate attachments (she was far away from her husband). She sent the money back to her husband for plans to have a shop as their family business. She additionally recognised the meaning of the extra money to her sons' education.

Years later, her mother was desperately informed that her husband betrayed her by having an affair with another woman. His infidelity flashed repeatedly in her mind and eventually became her chief justification for 
prostituting herself; in addition to money, prostitution enabled her to satisfy her bodily needs and take revenge. As a wife who had been betrayed, she did not feel sorry for her husband anymore. Some secular achievements such as being able to create a brighter future for her son and buy beautiful clothes also satisfied her. Yet, she secretly felt guilty about her loss of morality and the shame she believed she was causing her parents.

The stories of the four participants illustrated their generative conceptualisations of themselves as family members or mothers. This is in line with a study conducted by Cox, Casablanca, and McAdams (2013) that highlighted that prostitutes who are mothers also have the broadest sense and interest in investing in their next generation's wellbeing and welfare.

\section{They were stuck in a new lifestyle as prostitutes mirroring the meritocratic moneyism of society}

The four participants of this study changed their employment from labourers to high-income city girls, which enabled them to keep sending money back to their families while leading wealthier lives. With their lives changed in some aspects, only money, social recognition, and explicit secular achievements, representing a distinguished status in a meritocratic atmosphere, offered them consolation and compensation for what they did.

As prostitutes, they seem to have discovered an approach to earning big money. Annie said: "I got NT $\$ 1000$ to NT $\$ 3000$ per time. I can get NT $\$ 50,000$ even NT\$70,000 a month; now this is big money, much more than my salary as a caregiver, [which is] only NT\$22,000 per month". Nina also expressed a similar opinion, "I got the money very fast. Sometimes, I meet three men a day, sometimes none. I can have my own schedule with some days off when I want to take a rest. I make lots of money". They could buy what they wanted for their families and also for themselves.

Furthermore, Jean said, "My mom is happy to use my money to fix our house and fence that has broken for years. My younger sister continues her high school; I saw her photos with a nice uniform. I am so happy". As high earners, who could also take better care of themselves, they presented a portrait of accomplishment of long-term dreams through wearing cosmetics and fashionable garments.

The women of this study seemed to be ecstatic about getting those extra monies that went beyond their original expectations. The "big money" they earned also seemed to compensate all of them for their engagement in prostitution, at least in some aspects and a certain degree. Despite the hardships they suffered, "big 
money" helped them reach their expected working overseas goals. None of them told their parents or other family members about how they earned money. Yet for all the honors expressed by their family members; tales of grief and sorrow continued to impact them inwardly in a profound manner.

\section{They tried to rationalise their behaviour by creating and adapting their reasoning to their circumstances}

According to previous research by Cushman (2020), individuals fill the dissonance in their actions or behaviours by improving their reasoning. They adapt their beliefs, desires, instincts, norms, and habits to rationalise their behaviours or actions.

The four participants shifted their beliefs, desires, instincts, norms, and habits to rationalise their behaviours as prostitutes. For example, when the researchers ask about how they perceived their jobs as prostitutes, they answered: "I knew it is shameful to do this job..."; "I have been feeling [did feel] shameful to have sex with men at [the] beginning...". However, they continued their answers with "but..." to adapt their beliefs.

Like other migrant workers, they also expressed a naivety in their initial expectations regarding coming to Taiwan: "I will do my job diligently, send [some of my] salary [back home] for a monthly allowance, and save the rest for a future plan back home to live together with my family". However, when they decided to choose another pathway by becoming prostitutes, their goals were no longer as simple as before. Jean said, "I get extra money just in a couple of hours while enjoying the sex".

Asian norms that stigmatise prostitution as immoral caused these women to keep a distance from their original communities. They are only associated with their "similar" community. Maria said, "I have never contacted my agents. All persons I connect with are my customers and friends working as prostitutes". Annie also stated, "my son already does not have a father, so I hide the fact from him that I am like this [doing prostitution] in Taiwan".

Furthermore, Maria, Annie, and Nina, all of whom already have children, needed to send money back to their family as usual, regardless of their situation in Taiwan. As Maria said, "the main reason at that time is my family's concerns; I must get money and send it to my family". Jean, a single woman, who had already enjoyed sex with various partners while back in her home country, however, differed in her narrative. She mentioned: "I call them sex-partners not a customer because I only make love with people I like. If I do not like [them], even I get high paid, I will not do it". 


\section{Discussions}

After simultaneously reflecting and validating data with previous studies and relevant theories, the researchers' intense analyses revealed some crucial issues as illustrated in Figure 5 and further discussed below.

\section{It is human nature to pursue a better life}

A study from Anderson, Hildreth, and Howland (2015) recognised human desires for a better life as fundamental human motives. Most people endeavour to find the best possible means of taking care of themselves and moving forward when encountering undesirable circumstances. Moreover, based on the theory of social identity theory about human desires, people with less wealth and status in fact demand more wealth and status (Wang, Jetten, \& Steffens, 2019).

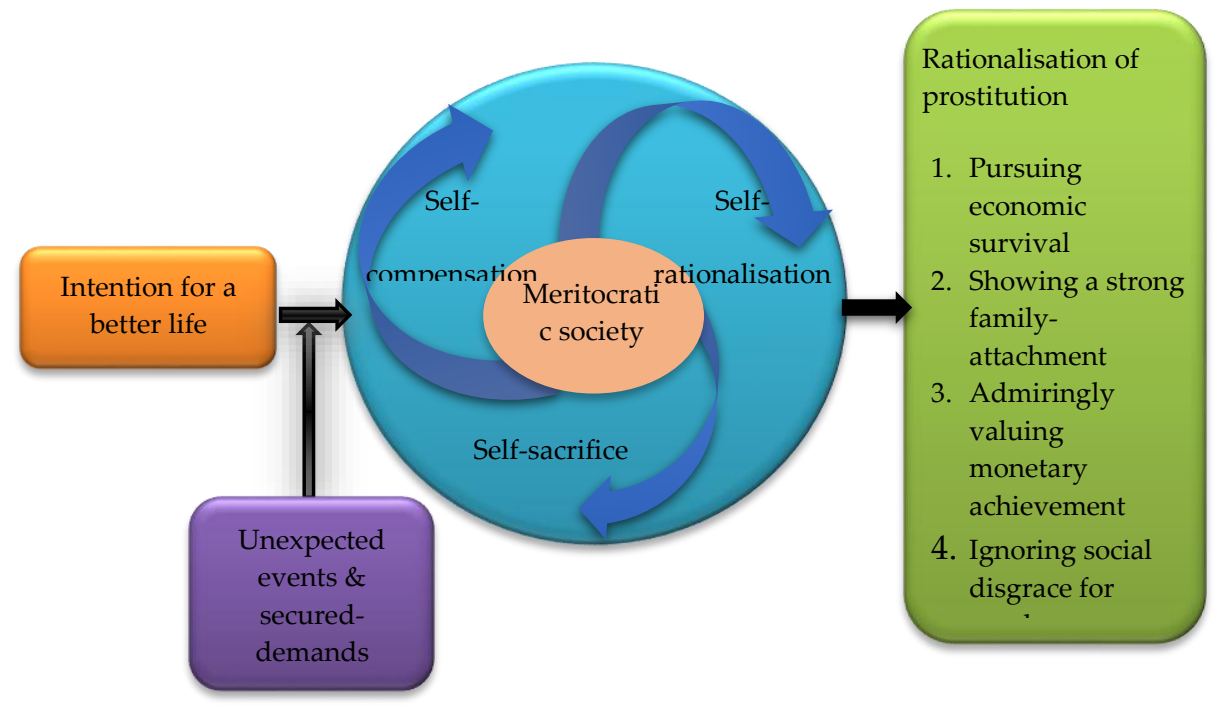

Figure 5: The vulnerability of prostitutes and rationalisation of prostitution

The participants' initial intentions were pure and simple; they intended to pursue better lives for themselves and their families. On average, we expect people to be happier the more money they have. However, the economic theory explains that there is a paradoxical phenomenon inherent in the money-happiness relationship. The 'hedonic adaptation' theory explains that the phenomenon of money-valued achievement cannot fully ensure an individual's happiness (Galiani, Gertler, \& Undurraga, 2018). 
In Asian cultural contexts, people perceive contributions to their family as a fundamental responsibility and honourable mission, even if it means sacrificing themselves in the process

In Asian cultural contexts, after marriage and childbirth, it is natural to assume that the husband would act as the breadwinner and the wife as the homemaker. However, in some conditions, a woman has more opportunities to offer the family a financial contribution (Liang, 2011). It is also a common practice for each family member, especially the mother, to contribute financially to the family as this is seen as an honourable mission to secure their needs even if she has to sacrifice herself in the process (Shohet, 2013).

The participants sensed a moral worth when they contributed to their family. They sacrificed themselves for their families, missing the opportunity to stay together with them when their families were the centrepiece of their lives. Being far away from their families, the participants suffered from homesickness and many other distresses like communication difficulties, culture shock, and disparagement from others ( $\mathrm{Liu}, 2015)$. Later, they drowned themselves in the world of prostitution, which 'disgraced' them, took away their freedom, or led to their stigmatisation by society even as it offered them various secular accomplishments.

\section{A high pursuit of secular achievements prevails in meritocratic societies}

To some degree, the meritocratic moneyism of society regulates social goals and sets guidance on individual life. Consequently, individuals engage more with goal-directed approaches; they work hard to aim at goals and achieve others' respect and admiration. For instance, individuals contrive to increase their monetary value by accumulating money, luxury items, jewellery, and other material items because they believe it makes life more valuable and is a more straightforward tool for social mobility (Gugushvili, 2016).

This environment influenced the participants' mindsets, choices, and behaviours. They strived to create wealth, prosperity, and reputation for themselves but subsequently became trapped in a scarcity mindset.

\section{'Disgraced' individuals attempt to compensate for their guilt and shame by building up a family reputation}

When negative emotions like guilt and shame appear as individuals break the laws or norms, they will carry out self-compensation as a coping mechanism (Sheikh \& Janoff-Bulman, 2010). Moreover, Proulx and Heine (2010) demonstrated that selfcompensation alters attitude and prompts action when individuals face a threat or 
conflict that violates their own beliefs. Individuals also use self-compensation to close the gap between who they are and who they want to be seen as.

The participants went against their values but inadvertently got trapped in the prostitution world that they threw themselves in. Their ensuing guilt and shame were compensated for by building up their reputation in their respective families. They want to be seen as good daughters/wives/mothers and reliable breadwinners for their families while hiding their identity as prostitutes. They persuade themselves into thinking that they would leave prostitution after returning to their homeland where they would later become the good daughters/wives/mothers they seek to be known as.

Three participants justified their behaviour through a series of perception transformation journeys, including self-sacrifice, self-compensation, and finally, self-rationalisation

Based on the system-justification theory, people tend to justify, defend and rationalise their behaviours, actions, or status quo to avoid threats or reduce uncertainties (Jost \& Hunyady, 2005). Although most people are at least somewhat motivated to justify their behaviours, the degree of motivation can vary due to dispositional and situational factors, and people who are highly motivated to action often sacrifice their interests. Based on rationalisation theory, people also self-rationalise by engaging in self-deception to justify immoral, deviant, or generally unacceptable behaviours or decisions (Von Hippel \& Trivers, 2011). In a nutshell, chosen behaviours are the result of a series of dynamic psychological processes. 


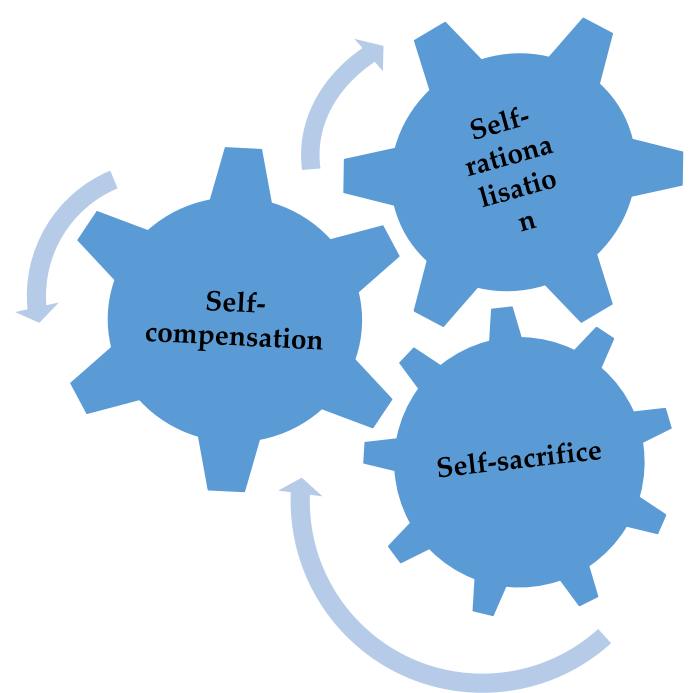

Figure 6: A series of dynamic psychological processes with reciprocal effects among self-sacrifice, self-compensation, and self-rationalisation

The four participants rationalised their behaviours through a series of dynamic psychological processes, with reciprocal effects occurring among selfsacrifice, self-compensation, and self-rationalisation, as illustrated by Figure 6. In becoming prostitutes, they perceived themselves as sacrificing themselves for a better future for themselves and their family; they compensated for their guilt and shame by building their own and their family's reputation and their good intentions; and, they rationalised their behaviours by means of their secular achievements.

\section{Conclusion}

It has been a spiritually enriching journey listening to the participants' life stories; it has also been a shocking experience that has stimulated the researchers to reflect on the effects of meritocracy, which effectively motivates individuals to reach a higher performance in the business world but which has paradoxical effects in other circumstances. Unfortunately, this study revealed that meritocracy moneyism unconsciously misleads people and traps them in a dark abyss where they experience a scarcity mindset, lack of self-consciousness, and selfunderstanding. Moreover, their sense of career value and even morality and integrity, are subconsciously/unconsciously twisted and even suppressed.

The participants took employment overseas, like other individuals, so that 
they could strive for a better life quality and future for themselves and their families. However, overwhelmed by the social expectations in meritocratic communities, they oriented their achievement index toward secular achievements such "big money", family reputation, extravagant appearances, and the like. They ironically take the blame for meritocracy while suffering social stigmatisation and insults as "shameful prostitutes". Their prostitution could be ascribable to their innocence and/or material greed but should be more blamed on meritocratic moneyism prevailing in societies. That is, when people impetuously pursue wealth without clearly identifying their life goals, they sacrifice their happiness, meaning of life, and even honour without strong consciousness consideration.

This study additionally found that individuals in experiences such as working as prostitutes inevitably justify their behaviours through the psychological dynamics of self-sacrifice, self-compensation, and selfrationalisation. The participants live in their inner world where they create perceptions of temporary self-sacrifice for family members and rationalise their behaviours as valuable.

To conclude, this study, through the dynamic processes of intensive interviews, observations, and reflections, scrutinised the internal and external properties of phenomenal manifestations emphasising the vulnerability and rationalisation of Southeast Asian migrant prostitutes in Taiwan. In addition to any academic contributions, this study is expected to provide insightful and valuable suggestions to NGOs in Taiwan and Taiwan Migrant Labour associations so as to assist them in creating constructive interventions and/or policy amendments. In line with an excerpt from Deng et al.'s (2020) study which states, "... transnational mobility let [causes] many migrants from Southeast Asian countries to Taiwan end up losing their cultural capital and 'make money' instead", migrant workers find their identities challenged in societies characterised by meritocratic moneyism. These ladies need to maintain their autonomy and cultural identities by means of adapting themselves better to the Taiwan environment with strong mindsets, self-consciousness, and selfunderstanding, but also through the assistance of government and civil organisations.

This study undertook qualitative research approaches to understand the effects of meritocratic moneyism on the mindsets of migrant workers who turned to prostitution. Curiosities subsequently emerged in researchers' minds after taking retrospective reflections on the processes and results. Firstly, how do those families who have found out about their loved one's engaged in this trade perceive it within the context of secular monetary enhancement? What cognitive 
dissonances and rationalisations do they go through, assuming any exists. Secondly, since meritocratic moneyism affects people of both lower and upper social status, how do some people rediscover their core values and free themselves of the negative effects of meritocratic moneyism while following social norms?

\section{Acknowledgements}

The authors wish to thank the National Yunlin University of Science and Technology, as well as the Minister of Science and Technology (grant number: MOST 107-2511-H-224 -003 -MY2) for supporting this study.

\section{Disclosure Statement}

The authors reported this study without any potential conflict of interest. This research also did not receive any specific grant from funding agencies in the public, commercial, or non-profit sectors.

\section{References}

Anderson, C., Hildreth, J. A. D., \& Howland, L. (2015). Is the desire for status a fundamental human motive? A review of the empirical literature. Psychological Bulletin, 141, 574-601. https://doi.org/10.1037/ a0038781

Bell, D. A. (2012). Meritocracy is a good thing. New Perspectives Quarterly, 29(4), 918. https://doi.org/10.1111/j.1540-5842.2012.01339.x

Bettache, K., Chiu, C. \& Beattie, P. (2020). The merciless mind in a dog-eat-dog society: neoliberalism and the indifference to social inequality. Current Opinion in Behavioral Sciences, 34, 217-222. https://doi.org/10.1016/j.cobeha.2020.06.002

Campbell, A. (2015). Sex work's governance: Stuff and nuisance. Feminist Legal Studies, 23(1), 27-45. https://doi.org/10.1007/s10691-015-9279-3

Cargile, A. C., Mao, Y., \& Young, S. L. (2019). What's hard work got to do with it? Diversity course impact on meritocracy beliefs and dialogue about race. International Journal of Intercultural Relations, 68, 13-25. https://doi.org/10.1016/j.ijintrel.2018.10.005

Chen, A. S., Lin, Y. C., \& Sawangpattanakul, A. (2011). The relationship between cultural intelligence and performance with the mediating effect of culture 
shock: A case from Philippine laborers in Taiwan. International Journal of Intercultural Relations, 35(2), 246-258. https://doi.org/10.1016/j.ijintrel.2010.09.005

Cushman, F. (2020). Rationalisation is rational. Behavioral and Brain Sciences, 43(28), e28: 1-59. https://doi.org/10.1017/S0140525X19001730

Coşkun, E. (2018). Criminalisation and prostitution of migrant women in Turkey: A case study of Ugandan women. Women's Studies International Forum, 68, 85-93. https://doi.org/10.1016/j.wsif.2018.03.002

Cox, K. S., Casablanca, A. M., \& McAdams, D. P. (2013). "There is nothing good about this work:" Identity and unhappiness among Nicaraguan female sex workers. Journal of Happiness Studies, 14(5), 1459-1478. https://doi.org/10.1007/s10902-012-9390-y

Deng, J. B., Wahyuni, H. I., \& Yulianto, V. I. (2020). Labor migration from Southeast Asia to Taiwan: Issues, public responses and future development. Asian Education and Development Studies, 10(1), 69-81. https://doi.org/10.1108/AEDS-02-2019-0043

Duru-Bellat, M., \& Tenret, E. (2012). Who's for meritocracy? Individual and contextual variations in the faith. Comparative Education Review, 56(2), 223247. https://doi.org/10.1086/661290

Fergnani, A. (2019). Scenario archetypes of the futures of capitalism: The conflict between the psychological attachment to capitalism and the prospect of its dissolution. Futures, 105, 1-16. https://doi.org/10.1016/j.futures.2018.06.006

Galiani, S., Gertler, P. J., \& Undurraga, R. (2018). The half-life of happiness: Hedonic adaptation in the subjective wellbeing of poor slum dwellers to the satisfaction of basic housing needs. Journal of the European Economic Association, 16(4), 1189-1233. https://doi.org/10.1093/JEEA/JVX042

Gorry, J., Roen, K., \& Reilly, J. (2010). Selling yourself? The psychological impact of street sex work and factors affecting support seeking. Health and Social Care in the Community, 18, 492-499.

Gugushvili, A. (2016). Intergenerational social mobility and popular explanations of poverty: A comparative perspective. Social Justice Research, 29(4), 402428. https://doi.org/10.1007/s11211-016-0275-9

Hing, L. S. S., Bobocel, D. R., Zanna, M. P., Garcia, D. M., Gee, S. S., \& Orazietti, K. (2011). The merit of meritocracy. Journal of Personality and Social Psychology, 101(3), 433-450. https://doi.org/10.1037/a0024618 
Hoang, L. A. (2016). Vietnamese migrant networks in Taiwan: The curse and boon of social capital. Ethnic and Racial Studies, 39(4), 690-707. https://doi.org/10.1080/01419870.2015.1080381

Jost, J. T., \& Hunyady, O. (2005). Antecedents and consequences of systemjustifying ideologies. Current Directions in Psychological Science, 14, 260-265. https://doi.org/10.1111/j.0963-7214.2005.00377.x

Kim, C. H., \& Choi, Y. B. (2017). How meritocracy is defined today? Contemporary aspects of meritocracy. Economics and Sociology, 10(1), 112-121. https://doi.org/10.14254/2071-789X.2017/10-1/8

Konings, M. (2015). The emotional logic of capitalism: What progressives have missed. Stanford, CA: Stanford University Press.

Laurin, K., \& Jettinghoff, W. M. (2020). What kind of rationalisation is system justification? Behavioral and Brain Sciences, 43, e39. https://doi.org/10.1017/S0140525X19002243

Ledgerwood, A., Mandisodza, A. N., Jost, J. T., \& Pohl, M. J. (2011). Working for the system: Motivated defense of meritocratic beliefs. Social Cognition, 29(2), 322-340. https://doi.org/10.1521/soco.2011.29.3.322

Liang, L. F. (2011). The making of an 'ideal' live-in migrant care worker: Recruiting, training, matching, and disciplining. Ethnic and Racial Studies, 34(11), 1815-1834. https://doi.org/10.1080/01419870.2011.554571

Lin, S., \& Bélanger, D. (2012). Negotiating the social family: Migrant live-in elder care-workers in Taiwan. Asian Journal of Social Science, 40(3), 295-320. https://doi.org/10.1163/156853112X650854

Lipsey, D. (2014). The meretriciousness of meritocracy. The Political Quarterly, 85(1), 37-42. https://doi.org/10.1111/j.1467-923X.2014.12062.x

Liu, W. (2015). The embodied crises of neoliberal globalisation: The lives and narratives of Filipina migrant domestic workers. Women's Studies International Forum, 50, 80-88. https://doi.org/10.1016/j.wsif.2015.03.008

Meroe, A. S. (2014). Democracy, meritocracy, and the uses of education. The Journal of Negro Education, 83, 485-498. https://doi.org/10.7709/jnegroeducation.83.4.0485

Ministry of Labor Taiwan. (2021, April). Statistics of foreign workers in Taiwan. https://statdb.mol.gov.tw/html/mon/i0120020620e.htm

Neubauer, B. E., Witkop, C. T., \& Varpio, L. (2019). How phenomenology can help us learn from the experiences of others. Perspectives on Medical Education, 8, 90-97. https://doi.org/10.1007/s40037-019-0509-2

Nkansah-Amankra, S., Agbanu, S. K., \& Miller, R. J. (2013). Disparities in health, poverty, incarceration, and social justice among racial groups in the United 
States: A critical review of evidence of close links with neoliberalism. International Journal of Health Services, 43(2), 217-240. https://doi.org/10.2190/HS.43.2.c

Oliveira, A. (2012). Social control of immigrant sex workers: Transforming a group recognised as 'at risk' into a group viewed as 'a risk'. International Journal of Migration, Health, and Social Care, 8(1), 32-41. https://doi.org/10.1108/17479891211231392

Poocharoen, O. O., \& Brillantes, A. (2013). Meritocracy in Asia Pacific: Status, issues and challenges. Review of Public Personnel Administration, 33(2), 140163. https://doi.org/10.1177/0734371X13484829

Proulx, T., \& Heine, S. J. (2010). The frog in Kierkegaard's beer: Finding meaning in the threat-compensation literature. Social and Personality Psychology Compass, 4(10), 889-905. https://doi.org/10.1111/j.1751-9004.2010.00304.x

Shane, J., \& Heckhausen, J. (2017). It's only a dream if you wake up: Young adults' achievement expectations, opportunities, and meritocratic beliefs. International Journal of Psychology, 52(1), 40-48. https://doi.org/10.1002/ijop.12408

Seidman, I. E. (2006). Interviewing as qualitative research: A guide for researchers in education and the social sciences. New York: Teachers College Press, Columbia University.

Sheikh, S., \& Janoff-Bulman, R. (2010). The 'shoulds' and 'should nots' of moral emotions: A self-regulatory perspective on shame and guilt. Personality and Social Psychology Bulletin, 36(2), 213-224. https://doi.org/10.1177/0146167209356788

Shohet, M. (2013). Everyday sacrifice and language socialisation in Vietnam: The power of a respect particle. American Anthropologist, 115(2), 203-217. https://doi.org/10.1111/aman.12004

Smith, J. A., Flowers, P., \& Larkin, M. (2009). Interpretative phenomenological analysis: Theory, method, and research. London: SAGE.

Von Hippel, W., \& Trivers, R. (2011). The evolution and psychology of selfdeception. Behavioral and Brain Sciences, 34(1), 1-16. https://doi.org/10.1017/S0140525X10001354

Wang, Z., Jetten, J., \& Steffens, N. K. (2019). The more you have, the more you want? Higher social class predicts a greater desire for wealth and status. European Journal of Social Psychology, 50, 360-375. https://doi.org/10.1002/ejsp.2620 
Warikoo, N. K., \& Fuhr, C. (2014). Legitimating status: Perceptions of meritocracy and inequality among undergraduates at an elite British university. British $\begin{array}{llll}\text { Educational Research } & \text { 60urnal, }\end{array}$ https://doi.org/10.1002/berj.3108

Yacoub, A. R. (2019). Consensual sex work: An overview of sex-workers' human dignity in law, philosophy, and Abrahamic religions. Women's Studies International Forum, 76, 1-17. https://doi.org/10.1016/j.wsif.2019.102274

Cite this article (APA):

Wu, M.C, Cassim, F.A. K., Masrul, S. \& Yanato, R. (2021). The Vulnerability and Rationalisation of Prostitutes within Meritocratic Capitalism $\sim$ Southeast Asian Migrant Workers in Taiwan. JATI-Journal of Southeast Asian Studies, 26(1), 72-96

Date received: 18 February 2021 Date of accepted: 19 June 2021 